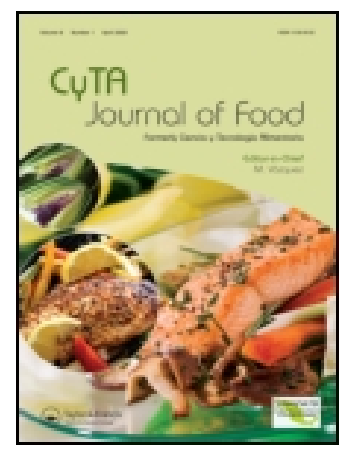

CYTA - Journal of Food

ISSN: 1135-8122 (Print) (Online) Journal homepage: https://www.tandfonline.com/loi/tcyt19

\title{
EFFECT OF RECOVERED SOLUBLE PROTEINS FROM PACIFIC WHITING SURIMI WASH WATER ON THE FUNCTIONAL AND MECHANICAL PROPERTIES OF ALASKA POLLOCK SURIMI GRADE FA EFECTO DE LAADICIÓN DE PROTEÍNAS SOLUBLES RECUPERADAS DELAGUA DE LAVADO DE SURIMI DE PACIFIC WHITING SOBRE LAS PROPIEDADES FUNCIONALES Y MECÁNICAS DE SURIMI DE ALASKA POLLOCK GRADO FA
}

G. Velazquez , P. Miranda-Luna , G. López-Echevarría , M. Vázquez , J. A. Torres \& J. A. Ramírez

To cite this article: G. Velazquez, P. Miranda-Luna, G. López-Echevarría, M. Vázquez, J. A. Torres \& J. A. Ramírez (2007) EFFECT OF RECOVERED SOLUBLE PROTEINS FROM PACIFIC WHITING SURIMI WASH WATER ON THE FUNCTIONAL AND MECHANICAL PROPERTIES OF ALASKA POLLOCK SURIMI GRADE FA EFECTO DE LAADICIÓN DE PROTEÍNAS SOLUBLES RECUPERADAS DELAGUA DE LAVADO DE SURIMI DE PACIFIC WHITING SOBRE LAS PROPIEDADES FUNCIONALES Y MECÁNICAS DE SURIMI DE ALASKA POLLOCK GRADO FA, CYTA - Journal of Food, 5:5, 340-345, DOI: 10.1080/11358120709487710

To link to this article: https://doi.org/10.1080/11358120709487710

(2) Copyright Taylor and Francis Group, LLC

Submit your article to this journal

III Article views: 296

Q View related articles ¿

Citing articles: 9 View citing articles $\longleftarrow$ 


\title{
EFFECT OF RECOVERED SOLUBLE PROTEINS FROM PACIFIC WHITING SURIMI WASH WATER ON THE FUNCTIONALAND MECHANICAL PROPERTIES OF ALASKA POLLOCK SURIMI GRADE FA
}

\section{EFECTO DE LAADICIÓN DE PROTEÍNAS SOLUBLES RECUPERADAS DELAGUADE LAVADO DE SURIMI DE PACIFIC WHITINGSOBRE LAS PROPIEDADES FUNCIONALES Y MECÁNICAS DE SURIMI DE ALASKA POLLOCK GRADOFA}

\author{
Velazquez, G. ${ }^{1}$; Miranda-Luna, P. ${ }^{1}$; López-Echevarría, G. ${ }^{1}$; Vázquez, M. ${ }^{1,3}$; Torres, J.A. ${ }^{2 *}$; Ramírez, J. A. ${ }^{1}$ \\ ${ }^{1}$ Department of Food Science \& Technology, UAM Reynosa-Aztlán, Universidad Autónoma de Tamaulipas, Apdo. \\ Postal 1015, Reynosa, Tamaulipas, 88700 México. (USA Address: PMB 374, 501 N. Bridge St., Hidalgo, TX 78557). \\ ${ }^{2}$ Food Process Engineering Group, Dept. of Food Science \& Technology, Oregon State University, Corvallis, OR \\ 97331-6602, USA. ${ }^{3}$ Area Tecnología de los Alimentos, Facultad de Veterinaria, Universidad de Santiago de \\ Compostela, 27002 Lugo, Spain.
}

Recibido/Received 05-06-2007; aceptado/accepted 09-09-2007

*Autor para la correspondencia/Corresponding author. E-mail: J_Antonio.Torres@OregonState.edu

\begin{abstract}
Soluble proteins from surimi wash water (SWW) can be insolubilized by complexing with chitosan-alginate allowing its recovery and the reduction of the organic matter in the processing water discharged from surimi processing plants. The objective of this work was to evaluate the effect of adding soluble proteins recovered from Pacific whiting SWW on the mechanical and functional properties of commercial Alaska Pollock surimi grade FA. Levels evaluated were 0 (control), 10 , 30 and $50 \mathrm{~g}$ insolubilized SWW solids/kg Alaska Pollock grade FA surimi. The mechanical and functional properties of Alaska Pollock surimi pastes and gels were characterized by texture profile analysis (TPA), puncture test, expressible water (EW) and color attributes. TPA and puncture test parameters increased significantly $(\mathrm{P} \leq 0.05)$ when $10-30 \mathrm{~g} / \mathrm{kg}$ of soluble proteins from Pacific whiting SWW were added. EW values increased also, indicating a decrease of the water holding capacity. Color parameters showed that all surimi gels increased in redness, an undesirable effect in the production of Alaska Pollock grade FA surimi.
\end{abstract}

\section{Resumen}

Las proteínas solubles del agua de lavado del surimi (ALS) pueden ser insolubilizadas por medio de la formación de complejos con quitosano y alginato. Su recuperación por este método permite reducir la materia orgánica en el agua de proceso. El objetivo de este trabajo fue evaluar el efecto de la adición de proteína soluble recuperada del ALS de Pacific whiting sobre las propiedades mecánicas y funcionales de surimi comercial de Alaska Pollock de grado FA. Los niveles de adición evaluados fueron 0 (control), 10,30 y $50 \mathrm{~g}$ sólidos insolubilizados de ALS/ $\mathrm{kg}$ de surimi de Alaska Pollock de grade FA. Las propiedades mecánicas y funcionales se caracterizaron por medio del análisis de perfil de textura (TPA), prueba de punción, agua extraíble y atributos de color. Los valores de los parámetros de TPA y prueba de punción incrementaron significativamente $(\mathrm{P} \leq 0.05)$ cuando se adicionaron de 10 a $30 \mathrm{~g} / \mathrm{kg}$ de proteínas solubles de ALS de Pacific whiting. El agua extraíble también se incrementó, indicando un descenso de la capacidad de retención de agua. Los atributos de color indicaron que todos los geles de surimi incrementaron su color rojo, lo cual podría ser desfavorable para la producción de surimi de Alaska Pollock grado FA.

Keywords: Surimi, Surimi wash water, mechanical properties, Alaska Pollock Palabras clave: Surimi, agua de lavado de surimi, propiedades mecánicas, Pollock de Alaska

\section{INTRODUCTION}

The most utilized fish species for surimi production is Alaska Pollock followed by Pacific whiting. The first one is the most valuable species, used for SA and FA grade surimi production because of its superior gel strength
(Morrissey et al., 2000). Surimi processing water contains high organic loads and other food processing industries have the same environmental problem. For example, poultry processors are interested in improving by washing the color attributes of mechanically deboned chicken meat but this might induce a higher level of organic compounds in 
the processing water discharged (Bonato et al., 2006). The processing water generated by the surimi washing operations contains 0.5 to $2.3 \%$ of total proteins which are composed of sarcoplasmic proteins with small amounts of myofibrillar proteins (Lin and Park, 1996; Park and Morrisey, 2000; Morrisey et al., 2000). Surimi wash water (SWW) can be treated with a chitosan-alginate complex to recover soluble proteins as proposed by Savant and Torres (2000). Chitosan (Chi), the deacetylated derivative of chitin, is a highly versatile molecule with potential applications in the treatment of processing water, preparation of biodegradable films, medical treatments and many other applications (Savant and Torres, 2001). Chitin is a by-product recovered from crustacean processing, particularly shrimp. After the meat is extracted, the shells are demineralized using hydrochloric acid, washed and dewatered to obtain chitin, which is converted to chitosan by deacetylation (Savant and Torres, 1995). Alginate (Alg) on the other hand, is a polysaccharide extracted from the cell walls of brown seaweeds and used in the food industry as thickener, stabilizer or gelling agent.

Previous studies have demonstrated the effectiveness of using the Chi-Alg complex to remove soluble proteins from SWW (Wibowo et al., 2005; Savant and Torres, 2000, 2003). These studies included a centrifugation step of SWW to remove insoluble solids and adjusting the supernatant to $\mathrm{pH} 6$ before adding the Chi-Alg complex. A second centrifugation step was used to recover the soluble proteins absorbed by Chi-Alg. The highest soluble protein absorption rates were obtained using complexes with a Chi-Alg mixing ratio of 0.2 added to SWW at a concentration of $0.1 \mathrm{~kg} / 1000 \mathrm{~kg}$ SWW (Savant and Torres, 2000). The amount of soluble proteins that can be recovered from SWW will vary with the amount of protein present in SWW which ranges from 0.5 to $2.3 \%$ (Lin and Park, 1996; Park and Morrissey, 2000; Morrissey et al., 2000). The crude protein content of the dry soluble solids recovered by the second centrifugation step was $73 \%$ (Wibowo et al., 2004, 2005). The objective of this work was to evaluate the effect of adding recovered soluble proteins from Pacific whiting SWW to commercial Alaska Pollock grade FA surimi on the color, mechanical and functional properties of surimi gels.

\section{MATERIALSAND METHODS}

\section{Dry soluble SWW solids}

SWW obtained from Pacific whiting surimi processing was collected in four daily trips to the processing plant (Pacific Surimi Joint Venture L.L.C., Warrenton, OR), $\sim 28 \mathrm{~L}$ each time, and transported refrigerated to Corvalis, OR (USA). Sorbitol (1\%) was added as a cryoprotectant to prevent low temperature damage to SWW proteins. SWW was centrifuged for 20 min at $3100 \mathrm{~g}$ (Model J-6B, Beckman Coulter, Inc., Fullerton,
CA) and $4{ }^{\circ} \mathrm{C}$ to remove insoluble solids. The SWW supernatant was then adjusted to $\mathrm{pH} 6$ using $0.1 \mathrm{M} \mathrm{HCl}$. Then, Chi and Alg solutions were added at 0.2 mixing ratio (MR) and used at $0.1 \mathrm{~kg}$ per $1000 \mathrm{~kg} \mathrm{SWW}$. The mixture was agitated for $5 \mathrm{~min}$ at $130 \mathrm{rpm}$ and $20^{\circ} \mathrm{C}$ using an orbital shaker (New Brunswick Scientific Inc., New Brunswick, NJ) and allowed to stand at room temperature for $1 \mathrm{~h}$. The soluble proteins from SWW (SWW-SP) coagulated by the Chi-Alg complex were recovered by centrifugation at $3100 \mathrm{~g}$ for $20 \mathrm{~min}$ at $4{ }^{\circ} \mathrm{C}$ (Wibowo et al., 2004; Savant and Torres, 2003), freeze dried and stored under refrigeration until use in this study.

\section{Preparation of solubilized fish pastes and gels of fish}

The moisture content removed by freeze-drying from SWW-SP was restored by adding distilled water (11.7 g water/g solids). Rehydrated SWW-SP solids were mixed with commercial grade FA frozen Alaska Pollock surimi partially thawed and chopped into small pieces. Surimi paste samples $(500 \mathrm{~g})$ were prepared in a $5.5 \mathrm{~L}$ capacity Hobart cutter (Model 84145, Troy, Ohio) by mixing for 4 min commercial surimi with rehydrated SWW-SP at 0 (control), 10, 30 and $50 \mathrm{~g} / \mathrm{kg}$. Salt $(20 \mathrm{~g} / \mathrm{kg}$ ) was added to solubilize myofibrillar proteins and the final chopping temperature was kept below $15^{\circ} \mathrm{C}$. The paste was stuffed into stainless steel tubes (internal diameter $=20.8 \mathrm{~mm}$; length $=175 \mathrm{~mm}$ ) previously sprayed with commercial vegetable oil to prevent sticking. The tubes were capped before immersion for $15 \mathrm{~min}$ in a water bath at $90^{\circ} \mathrm{C}$ and then immediately placed for $30 \mathrm{~min}$ in a $4-5^{\circ} \mathrm{C}$ water bath. Fish gels were removed from the tubes and stored overnight at $4{ }^{\circ} \mathrm{C}$ in polyethylene bags before testing.

\section{Expressible water}

The expressible water content (EW) was measured as follows. Triplicate samples $(3 \pm 0.2 \mathrm{~g})$ of solubilized fish paste or gel, placed between two layers of filter paper, were loaded at the bottom of $50 \mathrm{~mL}$ centrifuge tubes and centrifuged at $1000 \mathrm{~g}$ for $15 \mathrm{~min}$ at $4{ }^{\circ} \mathrm{C}$. Immediately after centrifugation, the solubilized fish paste or gel samples were weighed and the EW was calculated by difference.

\section{Color}

Spectral reflectance of surimi paste and gels were determined using a HunterLab MiniScan XE Plus spectrocolorimeter (model 45/0-L; Hunter Assoc., Reston, VA) calibrated against black and white tiles. $L^{*}, a^{*}$, and $b^{*}$ values, chroma $\left(\left[a^{* 2}+b^{* 2}\right]^{1 / 2}\right)$, and hue angle (arc tan $\left.\mathrm{b}^{*} / \mathrm{a}^{*}\right)$ were calculated based on illuminant $\mathrm{C}$ and the $2^{\circ}$ standard observer. Six samples were evaluated at each SWW-SP concentration level.

\section{Back-extrusion of fish paste}

A TA.XT2i Texture Analyzer (Stable Micro Systems, Vienna Court, U.K.) with a back extrusion rig (model A/BE, $40 \mathrm{~mm}$ inner diameter, Stable Micro Systems) was used to 


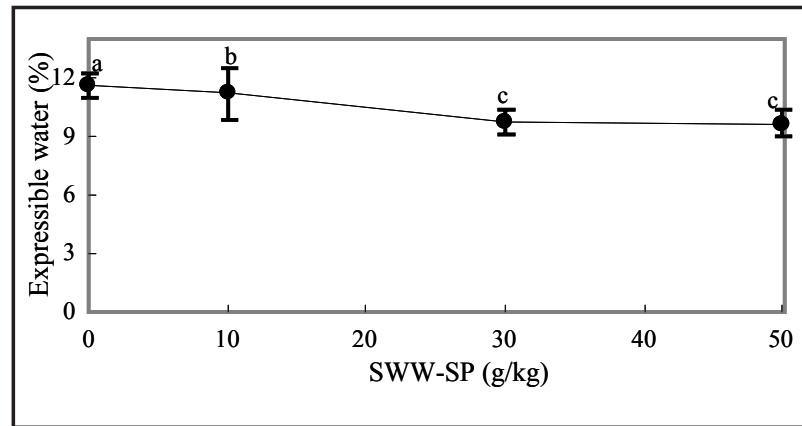

Figure 1. Effect of the added level of soluble protein from surimi wash water (SWW-SP) on the expressible water of Alaska Pollock grade FA surimi pastes. Mean values of six replicates. Bars shows standard deviation. Different letters indicate significant differences between treatments $(\mathrm{P} \leq 0.05)$.

Figura 1. Efecto del nivel de adición de proteínas solubles obtenidas del agua de lavado de surimi (SWW-SP) en el agua extraíble de la pasta de surimi de Alaska Pollock grado FA. Valores promedio de 6 réplicas. Las barras muestran la desviación estándar. Distintas letras indican diferencias significativas entre tratamientos $(P \leq 0,05)$.

measure the force required for the product to be extruded around a $35 \mathrm{~mm}$ piston disc. Samples $(30 \mathrm{~g})$ stored at room temperature $\left(26^{\circ} \mathrm{C}\right)$ for $2 \mathrm{~h}$ before analysis were introduced into the cell avoiding air bubbles and extruded at $1 \mathrm{~mm} / \mathrm{s}$ to $80 \%$ of its initial height $(17.5 \mathrm{~mm} \pm 1.28 \mathrm{~mm})$.

The maximum force and the area under the curve were defined as the firmness and consistency of the solubilized paste, respectively. Six samples were evaluated at each SWW-SP concentration level.

\section{Mechanical properties of fish gels}

Cylindrical surimi gel samples $(20.8 \mathrm{~mm}$ diameter x $25 \mathrm{~mm}$ height), kept in sealed plastic containers to avoid dehydration, were equilibrated to room temperature for $30 \mathrm{~min}$ before testing by Texture Profile Analysis (TPA) using a TA-XT2i Texturometer (Anton and Luciano, 2007). A $50 \mathrm{~mm}$ aluminum cylindrical probe (P/50) was used to compress samples at $1 \mathrm{~mm} / \mathrm{s}$ to $75 \%$ of their initial height.

The texturometer software (Texture Expert for Windows, Stable Micro Systems) was used to determine hardness, fracturability, springiness, cohesiveness and chewiness values.

Puncture test were performed by compressing surimi gels (20.8 $\mathrm{mm}$ diameter x $25 \mathrm{~mm}$ height) to $75 \%$ of initial height using a compression speed of $1 \mathrm{~mm} / \mathrm{s}$ and a spherical probe $12.7 \mathrm{~mm}$ diameter.

The breaking force $(\mathrm{g})$, deformation $(\mathrm{cm})$ and gel strength $(\mathrm{g} \times \mathrm{cm})$ for each treatment were measured. Samples (length $=2.5 \mathrm{~cm}$; diameter $=2 \mathrm{~cm}$ ) were placed at the base of texturometer, taking care that the spherical probe reached the sample at its center point. In both TPA and puncture tests, six samples were evaluated at each SWW-SP concentration level.

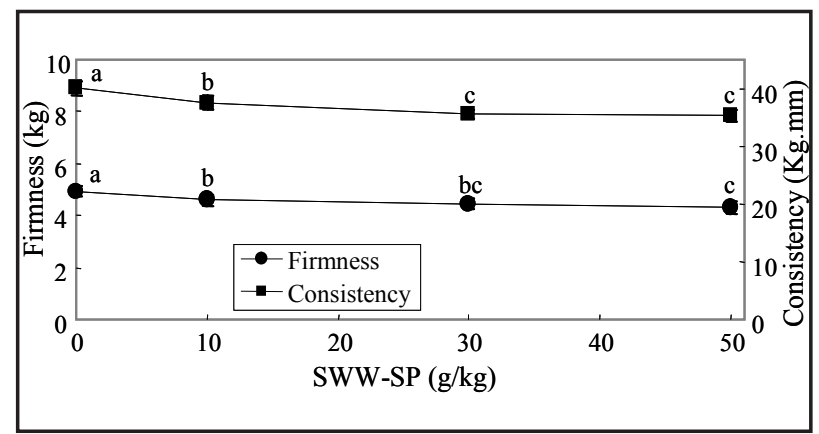

Figure 2. Effect of the level of added soluble protein from surimi wash water (SWW-SP) on the firmness and consistency of Alaska Pollock grade FA Surimi pastes. Mean values of six replicates. Bars shows standard deviation. Different letters indicate significantly differences between treatments $(\mathrm{P} \leq 0.05)$.

Figura 2. Efecto del nivel de adición de proteínas solubles obtenidas del agua de lavado de surimi (SWW-SP) en la firmeza y consistencia de pastas de surimi de Alaska Pollock grado FA. Valores promedio de 6 réplicas. Las barras muestran la desviación estándar. Distintas letras indican diferencias significativas entre tratamientos $(\mathrm{P} \leq 0,05)$.

\section{Statistical analysis}

Statistical analysis was performed using Statgraphics 5.0 (Bitstream Inc., Cambridge, MA). LSD's multiple range tests were used to determine significant difference $(\mathrm{P} \leq 0.05)$ among treatments.

\section{RESULTSAND DISCUSSION}

Soluble protein from surimi wash water (SWW-SP) recovered using a Chi-Alg mixture with a 0.2 mixing ratio was added to Alaska Pollock grade FA surimi paste. Changes in functional and mechanical properties as well in color attributes of surimi paste and surimi gel were then measured.

\section{Changes in surimi pastes}

EW values, inversely associated with water holding capacity (WHC), ranged from 11.6 to $9.6 \%$ (Figure 1). Samples containing 30 and $50 \mathrm{~g} / \mathrm{kg}$ of SWW-SP showed significantly lower EW values $(\mathrm{P} \leq 0.05)$ than the control, indicating that soluble protein improved the WHC of surimi pastes. Measurements by backward extrusion showed that adding SWW-SP to grade FA Pollock surimi caused a decrease in the firmness and consistency of solubilized fish pastes (Figure 2). Firmness decreased from $4.9 \mathrm{~kg}$ in control to $4.3 \mathrm{~kg}$ in surimi sample containing $50 \mathrm{~g} \mathrm{SWW-}$ $\mathrm{SP} / \mathrm{kg}$. Consistency decreased from $40.1 \mathrm{~kg} \mathrm{~mm}$ to $37.3 \mathrm{~kg}$ $\mathrm{mm}$. The decrease in firmness and consistency can be interpreted as a decrease in protein-water interaction with a consequent increase in protein-carbohydrate interactions (Uresti et al., 2003). In this study, the increase in the surimi pastes WHC caused by adding the Chi-Alg soluble protein mixture into the fish paste caused a decrease in firmness 
Table 1. Effect of the level of added soluble protein from surimi wash water (SWW-SP) on the color parameters of Alaska Pollock grade FA surimi paste. Mean values of six replicates with values in parenthesis showing standard deviation were significantly different (P 0.05) when the superscript is a different letter.

Tabla 1. Efecto del nivel de la adición de proteína soluble del agua de lavado de surimi (SWW-SP) en los parámetros de color de pastas de surimi de Alaska Pollock grado FA. Valores promedio de 6 réplicas con los valores entre paréntesis indicando la desviación estándar tienen diferencias significativas $(\mathrm{P} \leq 0,05)$ cuando el superíndice es una letra diferente.

\begin{tabular}{lccccc}
\hline $\begin{array}{l}\text { SWW-SP } \\
\text { content }(\mathbf{g} / \mathbf{k g})\end{array}$ & $\mathbf{L}^{*}$ & $\mathbf{a}^{*}$ & $\mathbf{b}^{*}$ & Chroma & Hue \\
\hline \multirow{2}{*}{0} & $64.8^{\mathrm{a}}$ & $-2.44^{\mathrm{a}}$ & $8.3^{\mathrm{a}}$ & $8.67^{\mathrm{a}}$ & $106.3^{\mathrm{a}}$ \\
& $(0.52)$ & $(0.07)$ & $(0.18)$ & $(0.16)$ & $(0.66)$ \\
\multirow{2}{*}{10} & $65.6^{\mathrm{a}}$ & $-1.79^{\mathrm{b}}$ & $11.3^{\mathrm{b}}$ & $11.5^{\mathrm{b}}$ & $99.0^{\mathrm{b}}$ \\
& $(0.77)$ & $(0.08)$ & $(0.35)$ & $(0.34)$ & $(0.58)$ \\
30 & $63.6^{\mathrm{a}}$ & $-0.32^{\mathrm{c}}$ & $15.1^{\mathrm{c}}$ & $15.1^{\mathrm{c}}$ & $91.2^{\mathrm{c}}$ \\
& $(0.98)$ & $(0.11)$ & $(0.3)$ & $(0.29)$ & $(0.43)$ \\
50 & $62.0^{\mathrm{b}}$ & $0.87^{\mathrm{d}}$ & $17.6^{\mathrm{d}}$ & $17.7^{\mathrm{d}}$ & $87.2^{\mathrm{d}}$ \\
& $(1.1)$ & $(0.1)$ & $(0.49)$ & $(0.49)$ & $(0.29)$ \\
\hline
\end{tabular}

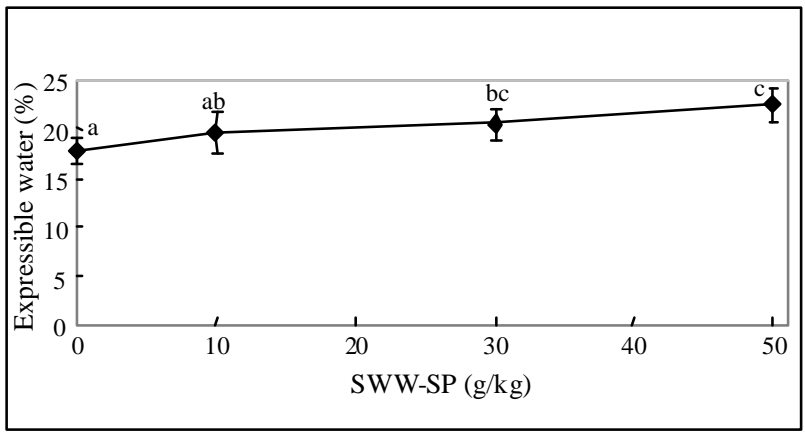

Figure 3. Expressible water of Alaska Pollock grade FA surimi gels containing different levels of the soluble protein recovered from surimi wash water (SWW-SP). Mean values of six replicates. Bars shows standard deviation. Different letters indicate significantly differences between treatments $(\mathrm{P} \leq 0.05)$.

Figura 3. Efecto del nivel de adición de proteínas solubles obtenidas del agua de lavado de surimi (SWW-SP) en el agua extraíble de geles de surimi de Alaska Pollock grado FA. Valores promedio de 6 réplicas. Las barras muestran la desviación estándar.Distintas letras indican diferencias significativas entre tratamientos $(\mathrm{P} \leq 0,05)$.

and consistency. This behavior suggests that adding the Chi-Alg soluble protein mixture caused an increase in hydrocolloids-water interactions, which increased the fluency of surimi paste.

Surimi pastes containing SWW-SP showed changes in color attributes when compared with the control paste (Table 1). The $\mathrm{L}^{*}$ attribute decreased significantly $(\mathrm{P} \leq 0.05)$ only at the highest level of added SWW-SP (5 $\%)$. At all levels tested, the mixture increased both $\mathrm{a}^{*}$ and $b^{*}$ parameters in surimi pastes, reflecting an increase in redness and yellowness. Moreover, the effect on these two parameters increased with the level of SWW-SP added. The hue angle and chrome attributes were significantly modified by adding SWW-SP. Increasing the amount of SWW-SP added caused a change of color (hue angle) in

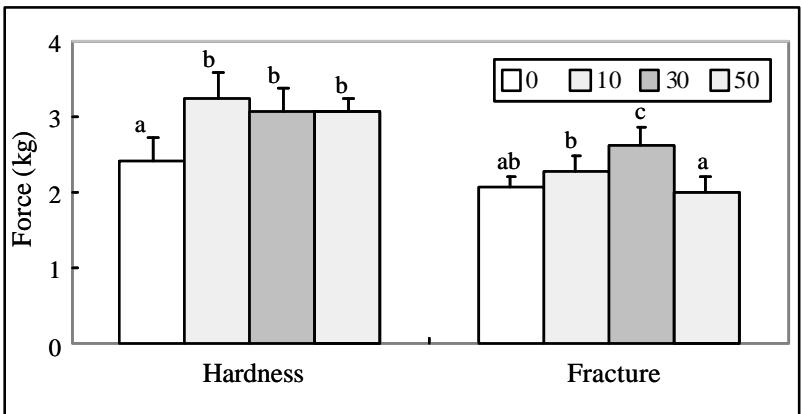

Figure 4. Effect of the level of added soluble protein from surimi wash water (SWW-SP) on the hardness and fracture of Alaska Pollock grade FA surimi gels. Mean values of six replicates. Bars shows standard deviation. Different letters indicate significantly differences between treatments $(\mathrm{P} \leq 0.05)$.

Figura 4. Efecto de la concentración de proteína soluble del agua de lavado de surimi (SWW-SP) en la dureza y fractubilidad de los geles de surimi de Alaska Pollock grado FA. Valores promedio de 6 réplicas. Las barras muestran la desviación estándar. Distintas letras indican diferencias significativas entre tratamientos $(\mathrm{P} \leq 0,05)$.

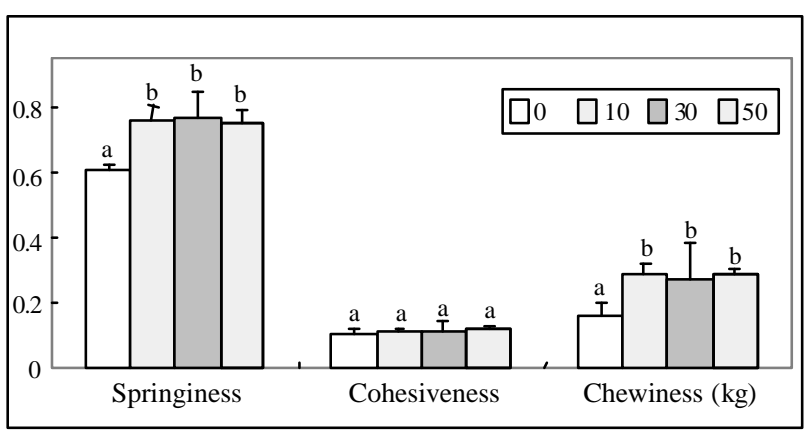

Figure 5. Effect of the level of added soluble protein from surimi wash water (SWW-SP) on the springiness, cohesiveness and chewiness of Alaska Pollock grade FA surimi gels. Mean values of six replicates. Bars shows standard deviation. Different letters indicate significantly differences between treatments $(\mathrm{P} \leq 0.05)$.

Figura 5. Efecto del nivel de la adición de proteína soluble del agua de lavado de surimi (SWW-SP) en la elasticidad, cohesividad y masticabilidad de los geles de surimi de Alaska Pollock grado FA. Valores promedio de 6 réplicas. Las barras muestran la desviación estándar. Distintas letras indican diferencias significativas entre tratamientos $(\mathrm{P} \leq 0,05)$.

the paste, passing from a yellowed to a reddish color while the change in chroma indicated an increase in color intensity. These results indicate that SWW-SP induced an increase in redness, which is considered undesirable in surimi production.

\section{Changes in surimi gel properties}

Adding SWW-SP increased the EW values of surimi gels from 17.9 to $22.4 \%$ indicating a loss in water holding capacity (Figure 3). Changes in hardness and fracturability are shown in Figure 4. Hardness values ranged from 2.4 to $3.3 \mathrm{~kg}$ while fracturability varied from 2.0 to $2.6 \mathrm{~kg}$. Hardness values of surimi gels containing 10 to $50 \mathrm{~g} / \mathrm{kg}$ of SWW-SP were significantly higher $(\mathrm{P} \leq 0.5)$ 


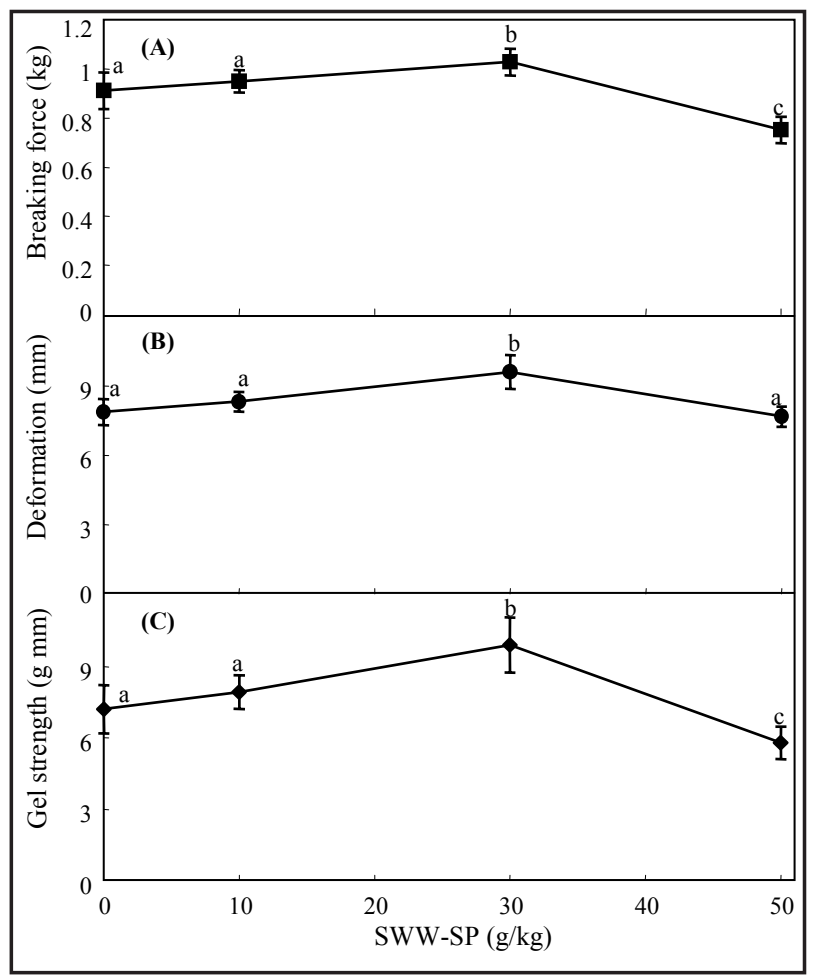

Figure 6. Effect of the level of added soluble protein from surimi wash water (SWW-SP) on the breaking force, deformation and gel strength of Alaska Pollock grade FA surimi gels. Mean values of six replicates. Bars shows standard deviation. Different letters indicate significantly differences between treatments $(\mathrm{P} \leq 0.05)$.

Figura 6. Efecto del nivel de la adición de proteína soluble del agua de lavado de surimi (SWW-SP) en la fuerza de corte, deformación y fuerza de gel de los geles de surimi de Alaska Pollock grado FA. Valores promedio de 6 réplicas. Las barras muestran la desviación estándar. Distintas letras indican diferencias significativas entre tratamientos $(\mathrm{P} \leq 0,05)$.

than the control; however, the level of addition had no significant effect. The fracturability value of surimi gel containing $30 \mathrm{~g} / \mathrm{kg}$ of the mixture was significantly higher than fracturability value of control surimi. This parameter decreased slightly for samples containing $50 \mathrm{~g} \mathrm{SWW-SP/}$ $\mathrm{kg}$ but remained similar to the fracturability value of the control gel. Springiness values ranged from 0.61 to 0.77 , cohesiveness varied from 0.10 to 0.12 and chewiness varied from 0.16 to 0.29 (Figure 5). The springiness and chewiness values of surimi gels increased by adding 10 to $50 \mathrm{~g} \mathrm{SWW-}$ $\mathrm{SP} / \mathrm{kg}$ with no significant difference observed between the levels added. Cohesiveness was very low for all gel samples and no significant effect of adding SWW-SP was observed.

The puncture test parameters of surimi gels were modified by the addition of SWW-SP (Figure 6). Breaking force values varied from 912 to $1029 \mathrm{~g}$, deformation varied from 7.87 to $9.61 \mathrm{~mm}$ and gel strength varied from 7.21 to $9.91 \mathrm{~g} \cdot \mathrm{mm}$. Surimi gels containing $30 \mathrm{~g} \mathrm{SWW-SP} / \mathrm{kg}$ showed the highest value for all three parameters (breaking force, deformation and gel strength) and were significantly higher
Table 2. Effect of the level of added soluble protein from surimi wash water (SWW-SP) on the color parameters of Alaska Pollock grade FA surimi gel. Mean values of six replicates with values in parenthesis showing standard deviation were significantly different $(\mathrm{P} \leq 0.05)$ when the superscript is a different letter.

Tabla 2. Efecto del nivel de la adición de proteína soluble del agua de lavado de surimi (SWW-SP) de Alaska Pollock grado FA en los parámetros de los geles de surimi. Valores promedio de 6 réplicas con los valores entre paréntesis indicando la desviación estándar tienen diferencias significativas $(\mathrm{P} \leq 0,05)$ cuando el superíndice es una letra diferente.

\begin{tabular}{lccccc}
\hline $\begin{array}{l}\text { SWW-SP } \\
\text { content }(\mathbf{g} / \mathbf{k g})\end{array}$ & $\mathbf{L}^{*}$ & $\mathbf{a}^{*}$ & $\mathbf{b}^{*}$ & Chroma & Hue \\
\hline 0 & $76.6^{\mathrm{a}}$ & $-3.41^{\mathrm{a}}$ & $7.9^{\mathrm{a}}$ & $8.6^{\mathrm{a}}$ & $113.4^{\mathrm{a}}$ \\
& $(0.57)$ & $(0.08)$ & $(0.2)$ & $(0.19)$ & $(0.64)$ \\
\multirow{2}{*}{10} & $75.7^{\mathrm{a}}$ & $-2.1^{\mathrm{b}}$ & $10.1^{\mathrm{b}}$ & $10.3^{\mathrm{b}}$ & $101.7^{\mathrm{b}}$ \\
& $(0.28)$ & $(0.14)$ & $(0.15)$ & $(0.13)$ & $(0.87)$ \\
30 & $72.7^{\mathrm{b}}$ & $-0.18^{\mathrm{c}}$ & $12.8^{\mathrm{c}}$ & $12.8^{\mathrm{c}}$ & $90.8^{\mathrm{c}}$ \\
& $(1.78)$ & $(0.14)$ & $(0.33)$ & $(0.33)$ & $(0.64)$ \\
50 & $70.9^{\mathrm{c}}$ & $1.45^{\mathrm{d}}$ & $15.1^{\mathrm{d}}$ & $15.2^{\mathrm{d}}$ & $84.5^{\mathrm{d}}$ \\
& $(1.17)$ & $(0.27)$ & $(0.36)$ & $(0.37)$ & $(0.92)$ \\
\hline
\end{tabular}

$(\mathrm{P} \leq 0.05)$ than values found for the surimi control gel. Samples containing $50 \mathrm{~g} \mathrm{SWW-SP/kg} \mathrm{had} \mathrm{significantly}$ lower values for all three parameters as compared to the control surimi gel. The increase in the mechanical properties of surimi gels containing up to $30 \mathrm{~g}$ SWW-SP/ $\mathrm{kg}$ may reflect free water reduction by SWW-SP absorption as evidenced by the increase in the WHC of surimi pastes. This may induce a higher level of protein-protein interaction and thus stronger gels. The decrease in mechanical properties observed at higher added SWWSP levels may be associated with a disruptive effect of the gel structure caused by the addition of SWW-SP.

The effect of the SWW-SP on color attributes of surimi gels is shown in Table 2. The addition of SWW-SP lowered $\mathrm{L}^{*}$ values from 78.6 to 70.9 with an effect proportional to the level of SWW-SP added. Also, the $\mathrm{a}^{*}$ and $b^{*}$ parameters increased with the SWW-SP level added indicating an increasing redness and yellowness, respectively. The increase in chroma value from 8.6 to 15.2 at the highest level of SWW-SP added indicates an increase in color intensity. The decrease in the hue angle value (113.4 to 84.5) with the level of SWW-SP added indicates also an increase in redness. In this study, all levels of added SWW-SP increased the redness of surimi gels with changes more significant in samples containing $50 \mathrm{~g} \mathrm{SWW}-\mathrm{SP} / \mathrm{kg}$.

\section{CONCLUSIONS}

SWW-SP increased the mechanical properties of Alaska Pollock grade FA surimi gels. However, it decreased the water holding capacity. SWW-SP recovered with the chitosan-alginate complex promotes protein-protein interactions when added at 10 to $30 \mathrm{~g} \mathrm{SWW-SP} / \mathrm{kg}$. However, added SWW-SP at the level $50 \mathrm{~g} / \mathrm{kg}$ lowered mechanical properties and WHC values. The chitosan- 
alginate complex appears to promote protein-water interactions in detriment of protein-protein interactions. On the other hand, SWW-SP addition increased the redness of surimi gels, which is considered a negative effect to their appearance. In summary, SWW-SP could be utilized at $10-30 \mathrm{~g} / \mathrm{kg}$ to improve mechanical properties of Alaska Pollock FA grade surimi gels with minor negative effects on color attributes. However, this may not be advisable in markets or applications where the whiteness of the surimi gels is a critical attribute.

\section{ACKNOWLEDGEMENTS}

This work was partially supported by Grant no. NA 16RG 1039 (Project no. R/SF-29) from the National Oceanic and Atmospheric Administration to the Sea Grant College Program at Oregon State University, and appropriations made by the Oregon State Legislature. Part of this study was supported by Grant no. TAMPS-2003-C02-14, FOMIXCONACYT, México

\section{REFERENCES}

Anton, A. A.; Luciano, F. B. 2007. Instrumental texture evaluation of extruded snack foods: a review. Ciencia y Tecnología Alimentaria 5, 245-251.

Bonato, P.; Perlo, F.; Teira, G.; Fabre, R.; Kueider, S. 2006. Nuggets with washed mechanically deboned chicken meat: frozen storage stability. Ciencia $y$ Tecnologia Alimentaria 5, 112-117.

Lin T. M.; Park J. W. 1996. Extraction of proteins from Pacific whiting mince at various washing conditions. Journal of Food Science 61, 432-8.
Morrissey, M. T.; Park, J. W.; Huang, L. 2000. Surimi processing waste: its control and utilization. In: Park JW, editor. Surimi and surimi seafood. New York: Marcel Deckker Inc. p 127-165.

Park, J. W.; Morrissey, M. T. 2000. Manufacturing of Surimi from light muscle fish. In: Park, J.W., editor. Surimi and surimi seafood. New York: Marcel Dekker Inc. p 23-58.

Savant, V.D.; Torres, J.A. 2000. Chitosan based coagulating agents for treatment of Cheddar cheese whey. Biotechnology Progress 16, 1091-1097.

Savant, V.D., Torres, J.A. 2001. Protein adsorption on chitosan polyanion complexes: Application to aqueous food processing wastes, p. 537-542. In Structure and Functionality of Biopolymers, Chen, H. and Weller, C. (ed.).

Savant, V.D.; Torres, J.A. 2003. Fourier transform infrared analysis of chitosan based coagulating agents for treatment of surimi waste water. Journal of Food Technology 1(2), 23-28.

Uresti, R. M.; López-Arias, N., Ramírez, J. A.; Vázquez, M. 2003. Effect of amidated low methoxyl pectin on the mechanical properties and colour attributes of fish mince. Food Technology and Biotechnology, 41, 131-136.

Wibowo, S.; Savant, V.; Cherian, G.; Savage, T. F.; Torres, J.A. 2005. Evaluation as a feed ingredient of surimi wash water protein recovered using a chitosanalginate complex. Journal of Aquatic Food Product Technology 14, 55-72.

Wibowo, S.; Velazquez, G.; Savant, V.; Torres, J.A. 2004. Surimi wash water treatment for protein recovery: effect of chitosan-alginate complex concentration and treatment time on protein adsorption. Bioresource Technology 96, 665-671. 